\title{
Activity profile between winners and losers among female exponents in international silat olahraga competition
}

\author{
J An PAWISTA*1,2 \& Mohamad Nizam Mohamed SHAPIE ${ }^{1,2}$ \\ ${ }^{1}$ Faculty of Sports Science \& Recreation, Universiti Teknologi MARA (UiTM), Shah Alam, Selangor \\ (Malaysia) \\ ${ }^{2}$ Seni Gayung Fatani Malaysia Association (PSGFM) (Malaysia)
}

8th IMACSSS International Conference Abstracts, Viseu (Portugal), October 10-12, 2019 Type: Oral communication

\begin{abstract}
Aim: The purpose of this study was to determine the details of activity that occurred during the match time between winners and losers among female exponents on Southeast Asian (SEA) Games 2017 silat olahraga competition. Methodology: Twenty female exponents from ten matches $(n=10)$ of silat olahraga on SEA Games 2017 were selected in this study. The notational analysis focused on fourteen different types of motion categories in silat olahraga: kick, punch, sweep, topple, block, catch, evade/dodge, block and kick, block and punch, block and sweep, fake kick, fake punch, self-release and others. The motion categories were divided into three outcomes, which were Hit Target (HT), Hit Elsewhere (HE) and Missing Opponent (MO). Matched paired $t$-tests were used to compare differences between winners and losers. Results: There were no significant differences in the activity profiles between winners and losers except for evade/dodge $(p=0.03)$, but there were significant differences in action outcomes in HT $(p=0.000)$ and MO $(p=0.025)$. This study showed that during the match the $51 \%$ of the actions were kicks, punches and sweeps. The results also showed that female exponents frequently used lower limbs to attack the opponents. Conclusion: The losers performed less HT actions and higher MO actions compared to the winners. The winners performed more successful actions than the losers during silat matches.
\end{abstract}

Keywords: Martial arts; combat sports; silat; silat olahraga; performance analysis; competition.

\section{Introduction}

Silat olahraga is a sport developed in many silat schools around the world (Anuar, 1993, Anuar, 2008). Olahraga means the ability of the pesilat (silat practitioner) to perform the silat techniques in combat with attack and defensive actions such as kicking, blocking, punching or any skill related to silat techniques (Shapie \& Elias, 2015; Shapie, Oliver, O'Donoghue \& Tong, 2013; Shapie, 2011). Notational analysis is one of the methods commonly used to record the practitioners' performance and it is focused on the key aspects determining their performance during competition (Hughes \& Franks, 2004; O'Donoghue, 2010). It has also become an important tool for coaches, athletes, sports organisations and academic researchers in sport (O'Donoghue, 2015; O’Donoghue \& Ingram, 2001; James, 2006). Every sport has its own style and way to evaluate the athletes' performance, and it is the same for the case of silat where it is being very useful to help coaches and athletes to improve their skills in terms of technical and tactical development (Shapie, Oliver, O'Donoghue \& Tong, 2008) and to find the way to defeat the opponent during the match time (Mackenzie \& Cushion, 2013). Previous research on the techniques and strategies used in defensive and offensive movements has focused in international mixed martial arts, boxing and karate competition. However, only one research conducted by Shapie et al. (2013) was specifically focused in silat, describing the activity profile during match time in competition. Getting accurate data thought notational analysis allows coaches to provide significant feedback for athletes to develop new strategies and to further optimise their sport performance (Hughes \& Bartlett, 2002; Sofwan, Norasrudin, Redzuan \& Mubin, 2012; Teodorescu \& Urzeală, 2013).

\footnotetext{
${ }^{*}$ Email: cheoann.jayn3@yahoo.com
} 


\section{Objectives}

The purpose of this study was to determine the details of activity that occurred during the match time between winners and losers among female exponents on Southeast Asian (SEA) Games 2017 silat olahraga competition

\section{Methodology}

The publicly available online videos of female silat olahraga SEA Games 2017 were the basis for this study. Ten matches were selected for this study, from A, B, D and E class. Each of the silat matches were played using Nacsport Elite (sports performance analysis software), which allows to pause and play back frame-by-frame for ease of use. For this study, 14 different types of motion categories were coded, including kick, punch, block, catch, topple, sweep, evade/dodge, self-release, block and punch, block and kick, block and sweep, fake punch, fake kick and others (Shapie et al., 2018). The motion categories were divided into three outcomes, which were Hit Target (HT), Hit Elsewhere (HE) and Missing Opponent (MO).

The observer manually registered each action performed by the pesilats in an observation sheet, to determine the frequency of motion categories used by the athlete as well as the start and the end of the match time. The video was played in slow motion mode (reduced to 50\%), and repeated if necessary to allow accuracy in the identification of each action. The collected data where then entered into the computer system, via representation on the screen of the silat match and specially designed screen functions for each exponent. For reliability of observations, the authors analyzed all the matches twice (24 hours of separation). Intra-class Correlation Coefficient (ICC) showed strong correlations (close to 1.00) between first and second observation for all actions. Matched paired $t$-tests were used to compare differences between winners and losers.

\section{Results}

The action most performed by the pesilats was kick $(n=499)$ actions followed by punch $(n$ $=183$ ) and sweep $(n=138)$. There were no actions of block and sweep during the matches. In terms of outcomes, HE achieved 1448 actions, followed by HT, with 98 actions and MO, with 89 actions. Winners performed more actions than losers (815 vs. 788). In addition, winners also performed more actions than losers in all actions except for kick, punch and self-release. Nevertheless, both groups only differed significantly in evade/dodge $(p=0.03)$. In terms of outcomes, winners performed more HT and less HE and MO than losers. Significant differences were found in HT $(p=0.000)$ and MO $(p=0.025)$.

\section{Discussion and conclusion}

Losers performed more HE and MO than winners, and they also performed more kicks and punches. This indicate that the losers applied more kicks and punches in attacking their opponents but did not hit the target accurately. Therefore, a key aspect in training is developing motion ability and accuracy. Not only in kicking and punching but in all actions involved in attacking the opponent. It is important to score during the match. Our study showed that the winners got more points with significantly higher number of outcomes in HT than losers. Even though the winners had less number of actions compared to losers, such as kick and punch, they hit on the target accurately. For this reason, it is not necessary for the winners to perform many kick and punch actions to win the match. So, the pesilats must focus on improving the quality of their training on attacking to make sure that they can hit the target and avoid hit elsewhere or missing the opponent. This study showed that there were significant differences on activity profiles between winners and losers but only in evade/dodge. Evade/dodge technique is one of the important defensive actions performed by pesilats during matches and requires them to avoid being hit by moving his/her body quickly either to the left or to the right (Shapie et al., 2013). Besides that, our study showed that the most frequent actions used by pesilats to attack involved lower limbs, such as kick, compared to other actions. Silat exponents have greater strength for kicking or other actions that involve lower limbs compared to upper limbs (Aziz, Tan, \& Teh, 2002). Finally, this study has provided further insight on silat by examining the athletes' actions during competition. 


\section{References}

Anuar, A. (1993). Silat olahraga. The art, technique and regulations (2nd edn.). Kuala Lumpur: Dewan Bahasa dan Pustaka.

Anuar, A. W. (2008). Silat Sejarah perkembangan kurikulum silat Melayu tradisi dan pembentukan kurikulum Silat Malaysia moden. Selangor, Malaysia: Hizi Print Sdn Bhd.

Aziz, A. R., Tan, B., \& Teh, K. C. (2002). Physiological responses during matches and profile of elite pencak silat exponents. Journal of sports science \& medicine, 1(4), 147-155.

Hughes, M. D., \& Bartlett, R. M. (2002). The use of performance indicators in performance analysis. Journal of Sports Sciences, 20(10), 739-754. doi: 10.1080/026404102320675602

Hughes, M., \& Franks, I. M. (2004). Notational analysis of sport: Systems for better coaching and performance in sport. London: Routledge.

James, N. (2006). The role of notational analysis in soccer coaching. International Journal of Sports Science \& Coaching, 1(2), 185-198. doi: 10.1260/174795406777641294

Mackenzie, R., \& Cushion, C. (2013). Performance analysis in football: A critical review and implications for future research. Journal of sports sciences, 31(6), 639-676. doi: $\underline{10.1080 / 02640414.2012 .746720}$

O'Donoghue, P. (2015). An introduction to performance analysis of sport. London: Routledge.

O'Donoghue, P. (2010). Research methods for sports performance analysis. London: Routledge.

O'Donoghue, P., \& Ingram, B. (2001). A notational analysis of elite tennis strategy. Journal of sports sciences, 19(2), 107-115. doi: 10.1080/026404101300036299

Shapie, M. N. M., Ali Janah, N. A., Kusrin, J., Tumijan, W., \& Elias, M. S. (2018). Activity profile between winners and losers in international silat olahraga matches. Journal of Physical Fitness, Medicine \& Treatments in Sports, 2(4), 1-4. doi: 10.19080/JPFMTS.2018.02.555592

Shapie, M. N. M., \& Elias, M. S. (2015). Silat Olahraga: The malay combat sports. Proceedings of the 1st world congress on health and martial arts in interdisciplinary approach hma, 2015. Czestochowa, Poland Achives of Budo Conference Proceedings.

Shapie, M. N. M., Oliver, J., O'donoghue, P., \& Tong, R. (2013). Activity profile during action time in national silat competition. Journal of Combat Sports and Martial Arts, 4(1), 75-79. doi: $10.5604 / 20815735.1073630$

Shapie, M. N., Oliver, J., O'donoghue, P., \& Tong, R. (2008). Distribution of fight and break time in international silat competition. In A. Hokelmann \& M. Brummond (Eds.), Performance Analysis of Sport VIII (pp. 667-672). Margeburg, Germany: Otto Von Guericke Universitat.

Shapie, M. N. M. (2011). Influence of age and maturation on fitness development, trainability and competitive performance in youth silat (Doctoral Dissertation). Cardiff Metropolitan University, Cardiff, UK. Retrieved from http://hdl.handle.net/10369/4068

Sofwan, N., Norasrudin, S., Redzuan, P., \& Mubin, A. (2012). Distinguishing playing pattern between winning and losing field hockey team in delhi fih road to london 2012 tournament. World Academy of Science, Engineering and Technology, International Journal of Social, Behavioral, Educational, Economic, Business and Industrial Engineering, 6(10), 2532-2535.

Teodorescu, S., \& Urzeală, C. (2013). Management tools in sports performance. Procedia-Social and Behavioral Sciences, 81, 84-88. doi: 10.1016/j.sbspro.2013.06.392 